\title{
Development of a vertical static test bench for amateur rocket engines
}

\section{Douglas Moraes Soares $^{\# 1}$, Francisco Telöken ${ }^{\# 1}$, Tiago Cassol Severo ${ }^{\# 1}$, Matheus Poletto ${ }^{\# 2}$}

\#1 Engineering and Exact Science, University of Caxias do Sul, Rio Grande do Sul, Brazil

\#2 Post-Graduate Program in Engineering of Processes and Technologies (PGEPROTEC),

Engineering and Exact Science, University of Caxias do Sul, Rio Grande do Sul, Bazil

\section{ABSTRACT}

The purpose of this work is to present the development of a static test bench for amateur rocket engines. This bench has electronic load cell assembled with four calibrated springs in order to measure the impulse and predict the rocket thrust with different dimensions of combustion chambers, nozzles and new kinds of fuel for amateur rockets. This static test bench has a vertical assembly projected in SolidWorks ${ }^{\circledR}$, and a computer interface using the LabView ${ }^{\circledR}$. The bench was tested using commercial rocket engines from $\mathrm{C}$ class, that must presented a total impulse of 5.01-10 N.s. The tests were done in triplicate. The results of thrust $(2.41 \pm 0.07 \mathrm{~N})$ and total impulse $(6.02 \pm 0.29 \mathrm{~N} . \mathrm{s})$ are in agreement with others values from the literature. The bench demonstrated to be safe and the obtained results are satisfactory for test rocket motors with a total impulse lower than 10 N.s.

Key words: Rocketry, static test bench, rocket engines, thrust, total impulse.

Corresponding Author: Matheus Poletto (mpolett1@ucs.br)

\section{INTRODUCTION}

Solid rocket motors are a very effective and relatively simple method of propulsion (Carter, 2008, Kumar and Anjaneyulu, 2015). They are used in amateur model rocketry and also in space launchers and defense applications, such as strategic and tactical missiles (Kuentzmann, 2004; Fabignon et al., 2016). The solid rocket engine is a device in which the propellants are burned and the resulting high-pressure gases are expanded through a specially shaped nozzle to produce thrust (Ziraksaz, 2009; Baldissera et al., 2016). However, after project and construct a solid rocket engine several tests for evaluating the rocket engine performance must be done to verify the stability and safety of the solid propellant rocket motor. Before launching a rocket, the performance of a rocket motor is generally verified in a test bench in ground.

Ground tests are normally performed in test bench to verify if the desirable characteristics and integrity of the develop rocket engine could be maintained prior to any rocket flight (Babayomi et al., 2013). The importance of conducting ground static tests is that they help to ascertain that motor characteristics are in line with design parameters (Babayomi et al., 2013).

A test bench for rocket engines must be designed and instrumented for determination of propellant's performance parameters. Some of them are engine's thrust values, propellant's 
flow rate, temperature and burning time (Favato, et al., 2015, Desrochers, 2001). The bench is normally segmented into three main parts, which are mechanical structure, hydraulics and control systems (Contaifer, 2009). The amateur rocket engine test bench is a structure, which incorporates a method for firmly mounting the rocket engine that will be tested, preferably in a nozzle-down altitude (Ziraksaz, 2009).

The test bench is based on a metallic structure that must be capable of withstanding the efforts imposed by the rocket motor that will be tested, an electronic load cell to determine the efforts promote by the solid propellant rocket motor and an acquisition system to obtain the data from the test (Ribeiro, 2013). In addition, the operator's station, which is really a part of the test bench, should be physically separated from the test bench proper by at least $50 \mathrm{~m}$ with a barricade between them (Ziraksaz, 2009; Ribeiro, 2013). The operator's station also contains the ignition system and the acquisition system. The greatest hazard in testing small rocket engines is from shrapnel in the event of engine explosion or disintegration (Ziraksaz, 2009). Therefore, the test bench proper should be suitably barricaded to reduce shrapnel effect in all directions (Ziraksaz, 2009).

On the other hand, the development of rockets during engineering courses is a worthy strategy in order to qualify and motivate future engineering students with hands-on activities. Besides that, the technology applied during the conception of an amateur rocket to reach $1000-1500 \mathrm{~m}$ altitudes is not a simple task and demands strong and continuous efforts of students from several engineering areas to development all rocket parts, such as propellant, ogive, fins, parachute and rocket motor. So, that main purpose of this work is develop and test a static test bench for rocket motors used in amateur rocketry.

\section{METHODOLOGY}

The vertical bench was projected using the SolidWorks ${ }^{\circledR}$ as platform. This bench was based on four calibrated springs and its basic structure was constructed using SAE 1020 steel, cut on laser cutting or stationary band saw machines. The extra parts were machined using a CNC machine.

The data acquisition was made with an electronic system based on compression load cell. This electronic system is able to conditioning and amplifying the DC electric signal from the cell, measured by $6 \frac{1 / 2}{2}$ multimeter and transmitted by USB connection to a computer with a LabView ${ }^{\circledR}$ programme implemented.

The electronic system is able to measure the time during the rocket motor test in microseconds. The load cell electronic signal relationship was $100 \mathrm{mV}$ is equal to $1 \mathrm{~kg}$. The bench was built to support $1000 \mathrm{~N}$-load engines, magnitude very comfortable to use in the actual level of the project and it will be able to considerable expansions of the engines in the future. The output electrical signal from load cell and system vary between 0 to $10 \mathrm{~V}$. The characterization of the electronic load cell and the springs used on the test bench was made using standard masses, respecting a step of $0.5 \mathrm{~kg}$ and measuring until $30 \mathrm{~kg}$ over the electronic system.

\section{RESULTS AND DISCUSSION}

The vertical static test bench projected by the rocket team as presented in Figure 1. The acquisition system was not shown. The structure has the dimensions of $355 \mathrm{~mm}$ x $355 \mathrm{~mm}$ by $384 \mathrm{~mm}$. The upper part of the vertical test bench has degrees of freedom to allow the axial movement of the rocket motor in order to push the load cell at the bottom, which is responsible for collecting thrust values. 


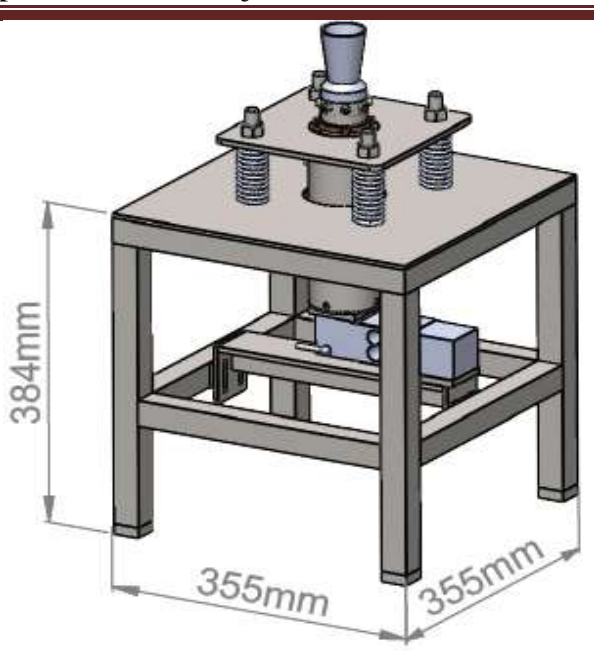

Fig 1: Vertical static test bench project

As discussed above, the electronic signal obtained from the bench was converted to mass and standard masses were used to compare both results. As can be seen in Figure 2 the standard deviation from the standard masses used and the measured mass was inferior of $2 \%$, in the range of $0.5-30 \mathrm{~kg}$. The results reveal that the bench was a satisfactory performance based on the preliminary tests.

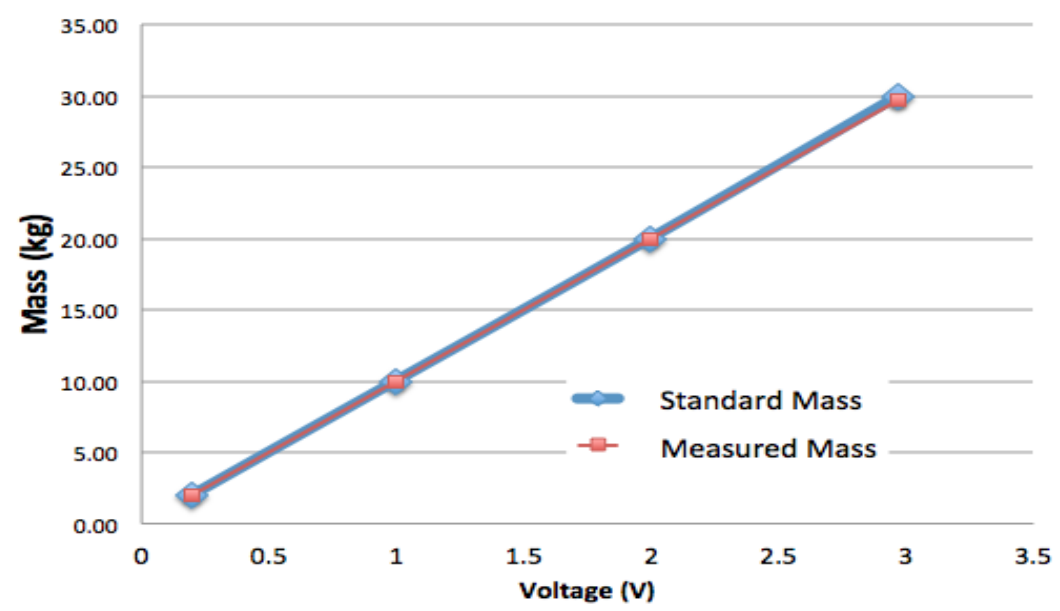

Fig 2: Comparison between standard masses and electronic signal converted to masses

After this initial test, the bench was tested using commercial rocket motors from $\mathrm{C}$ class. According to the literature, the $\mathrm{C}$ class rocket motor used in this work presented a total impulse between 5.01-10 N.s (Nakka, 1999). The tests were done in triplicate and the results are presented in Table 1.

Table1. Experimental results for the rocket motors tested.

\begin{tabular}{|c|c|c|c|}
\hline Samples & Thrust $(\mathrm{N})$ & Burning time $(\mathrm{s})$ & Total impulse (N.s) \\
\hline 1 & 2.37 & 2.40 & 5.69 \\
\hline 2 & 2.49 & 2.50 & 6.22 \\
\hline 3 & 2.36 & 2.60 & 6.14 \\
\hline Mean & $\mathbf{2 . 4 1}$ & $\mathbf{2 . 5 0}$ & $\mathbf{6 . 0 2}$ \\
\hline Standard deviation & $\mathbf{0 . 0 7}$ & $\mathbf{0 . 1 0}$ & $\mathbf{0 . 2 9}$ \\
\hline
\end{tabular}


The thrust and burning time presented similar values for all tested rocket engines. The total impulse obtained for the $\mathrm{C}$ class rocket engine tested was $6.02 \pm 0.29$. According to the literature (Marchi, 2011), the total impulse for the same commercial rocket engine used in this work was $6.76 \pm 0.77$. The difference between both values is $11 \%$.

Figure 3 shows the static vertical test bench with the data acquisition implemented and during the test of $\mathrm{C}$ class rocket motors. The total impulse obtained during the rocket motor tests are in agreement with the range values found in the literature. The bench demonstrated to be safe and the obtained results are satisfactory for test rocket motors with total impulse lower than 10 N.s.
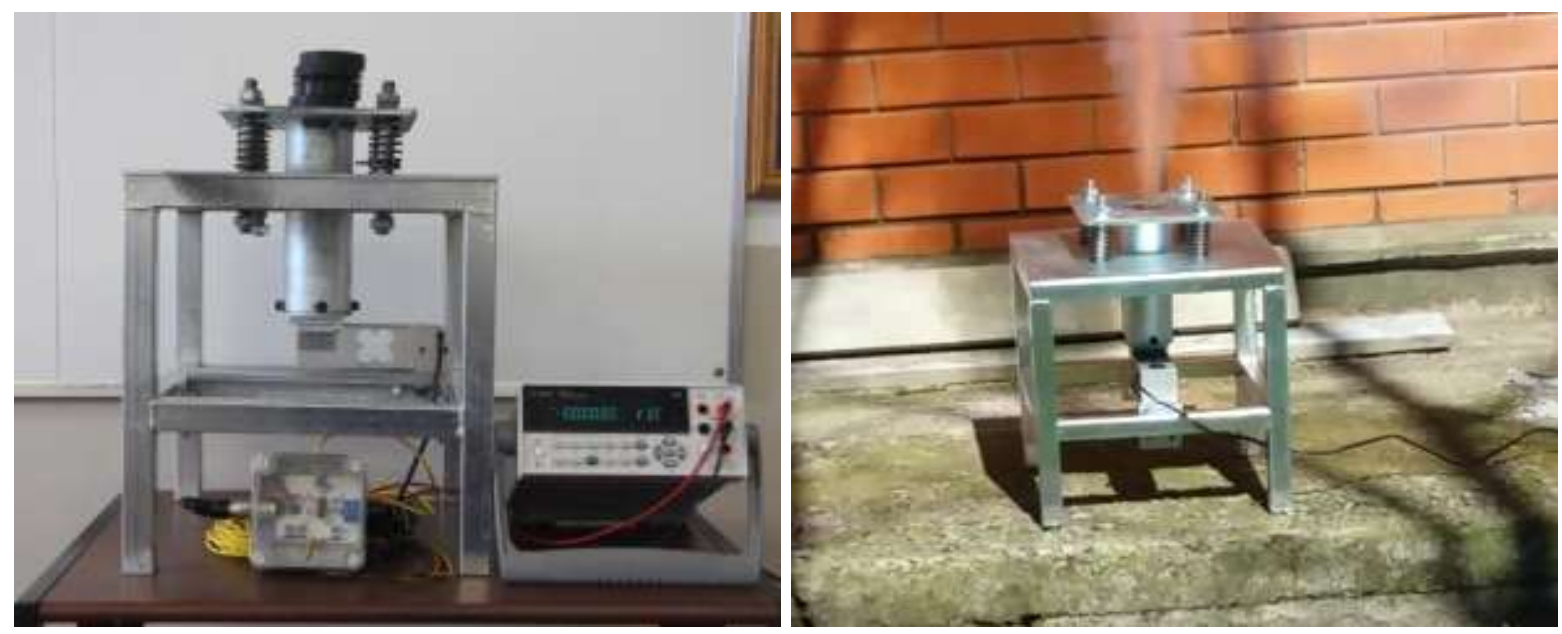

Fig 3: Static vertical test bench with the data aquisition implemented

\section{CONCLUSION}

In this work, the design, construction and implementation of a test bench for rocket engines has been described. The obtained results indicate that the system can be effectively used to perform the ground test of solid propellant rocket engines and also record thrust-time characteristics from rocket engines with total impulse lower than 10 N.s. The accuracy of the test bench can be improved by reducing the noise verified during the tests using a better electronic system to capture the signal from the load cell.

\section{ACKNOWLEDGMENTS}

The authors are grateful to the University of Caxias do Sul for the financial support to develop the test bench and the rocket technology project. Also, a special thanks to Engineer and Professor Cícero Zanoni to support our project anytime.

\section{REFERENCES}

1. Babayomi, O.O., Osheku, C.A., Adetoro, M.A.L., Okon, A., Opasina, A.O. 2013. Low cost ground test equipment for atmospheric rocket flights using embedded systems. 2013 IEEE International Conference on Emerging \& Sustainable Technologies for Power \& ICT in a Developing Society (NIGERCON). Imo State, Nigeria.

2. Baldissera, R., Soares, D., Gedoz, T., Morelatto, T., Severo, T., Poletto, M., 2016. Evaluation Of Rocket Propulsion Performance Using Potassium Nitrate/Sucrose And Aluminum/Ice As Propellants. Journal of Basic and Applied Research International, 19(3): 152-156. 
3. Carter, M.G., 2008. An investigation into the combustion and performance of small solid propellant rocket motors. Final Thesis Report. University of New South Wales. New South Wales, Australia.

4. Contaifer, R.A., 2009. Desenvolvimento de uma bancada de testes de propulsores híbridos de baixo empuxo. Master dissertation, INPE, São José dos Campos, Brazil.

5. Desrochers, M.F., Olsen, G.W., Hudson, M.K. 2001. A ground test rocket thrust measurement system. Journal of Pyrotechnics, 14, 50-55.

6. Fabignon Y, Anthoine J, Davidenko D, Devillers R, Dupays J, Gueyffier D, Hijlkema J, Lupoglazoff N, Lamet JM, Tessé L, Guy A, Erades C., 2016. Recent advances in research on solid rocket propulsion. Journal AerospaceLab AL 11-13:1-15.

7. Favato, L.F.and Magalhães Júnior, P.A.A., 2015. Linear static and dynamic analysis of rocket engine testing bench structure using the finite element method. Internacional Journal of Engineering Research and Applications, 5, 70-77.

8. Kuentzmann P., 2004. Introduction to solid rocket propulsion. No. RTO-EN-023. Office National D'etudes et de Recherches Aerospatiales Chatillion Cedex, France.

9. Kumar, A., Anjaneyulu, L. 2015. Emerging trends in instrumentation in rocket motor testing over three decades. Defence Science Journal, 65, 63-69.

10. Marchi, C. H. 2011. Desenvolvimento de kit didático de minifoguetes para a difusão e popularização da Astronáutica. Technical report. Process CNPq 550729/2008-9.

11. Nakka, R. KN-Sucrose propellant chemistry and performance characteristics. Richard Nakka's Experimental Rocketry Web Site. 1999.

12. Ribeiro, M.V.F., 2013. Metodologia de projeto e validação de motores foguete a propelente sólido. Master dissertation, São Paulo University, São Carlos, Brazil.

13. Ziraksaz, M.H., 2009. How to design, build and test smal sollid propellant rocket motor (Part one). 45th AIAA/ASME/SAE/ASEE Joint Propulsion Conference \& Exhibit, Denver, Colorado, USA. 